\title{
大気管支発生表層浸潤型扁平上皮癌症例 の臨床経過と剖検所見
}

\author{
Clinical course and autopsy findings of a case with \\ superficial infiltrating squamous cell carcinoma
}

正岡 昭 ·門田康正 ·清家洋二・谷岡恒雄 · 北村 旦 ${ }^{*}$ 泉 汎 **. 山梨八十穂 ${ }^{* *}$

抄録：右主気管支発生の非隆起性局平上皮癌症例が, 腫瘍の肉眼的識別が困難なため, 治癒手 術をうけられなかった。 8 年 5 ケ月後に死亡し, 剖検の結果, 広汎な粘膜内進展を主と し, リンパ性・血行性転移は極めて軽度であった。表層浸潤型扁平上皮癌の進展形式を 示す症例と考えられた。

右主気管支に発生した非隆起性の扁平上皮癌 に対し，病巣存在部位が確認できめため，治癒 手術を行ない得なかっな症例が, 術後 8 年 5 ケ 月で死亡し，剖検することができた。本症例は 肺門部早期肺癌の進展形式の一つを示している と考えられるので，二、に報告する。尚本症例 は, 肺門部早期肺癌困譜(医学書院 1976年刊 編集代表者, 池田茂人)の症例 9 である.1)

症例57才，男，服地商。

嗜好歴：紙巻きタバコ 1 日20本を 20 年間常用 してきた。

主訴：血痰。

現病歴：昭和 44 年 3 月，血痰をみたので，近 医受診、脸部X像にて異常なしといわれ，放置 していた。その後もしばしば血痰がみられたの で, 昭和 44 年 12 月, 大阪府立成人病センタ一受診.

大阪大学医学部策 1 外科

* 大阪大学医学部第 1 病理

**大阪中央病院
胸部X像に異常はみられないが，（図1）喀痰細 胞診にて，角化扁平上皮癌と診断された。気管 支鏡にて， carinaからわずかに入った右主気管 支の縦隔側壁(上葉支口の対側)に小範囲の erosionが㤎められ,この部の生検にて, 細胞異型性 のかなり強い扁平上皮癌と診断された。（図 2 ） 気管支造影では，この部に異常はみられない。 (図 3 )

治療歴：以上の所見から肺癌と診断され, 昭 和 45 年 2 月, 大阪大学第一外科入院. 気管支形 成を伴なう右上切もしくは右全摘を意眓して開 胸された、浸潤範囲を確認するため，まづ上葉 切除を行ったのち, 切断端より主父管支内腔を 観察したが，粘膜面に全く肉眼的異常を認めず， この部の擦過細胞診にても異常細胞を認めなか ったためそそのま、閉胸した。

術後も時々血痰が認められたが, その他には 症状なく, 就業を続けた。昭和 47 年 2 月施行し た気管支鏡検査では, 上葉支断端部の発赤, 易出 血性がみられたか，擦過細胞診で㓌性であった。 
Fig. 1. Routine chest film.

Abnormality is unremarkable.

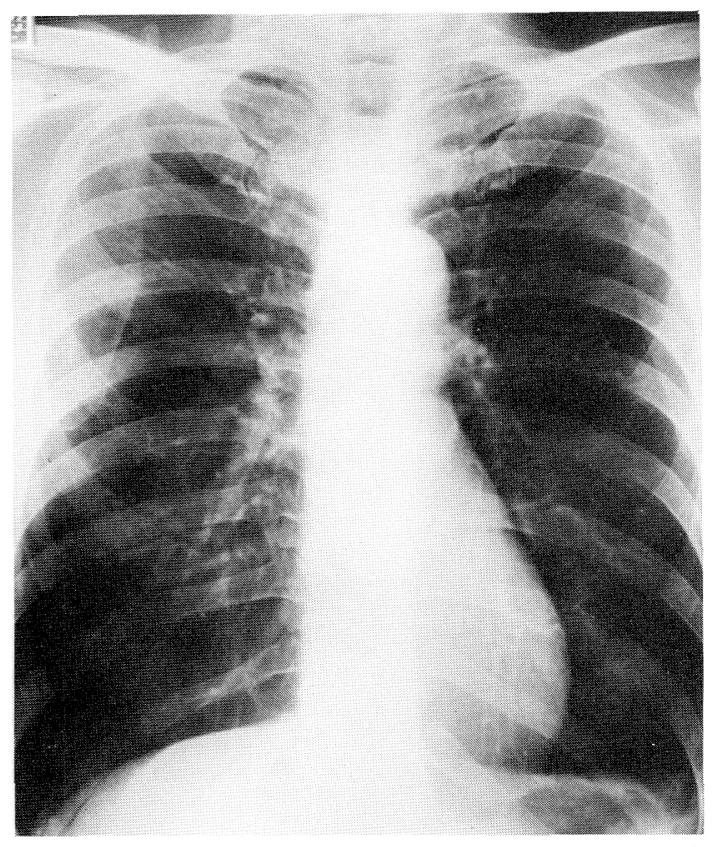

Fig. 2. Specimen by bronchoscopical biopsy revealed squamous cell carcinoma.

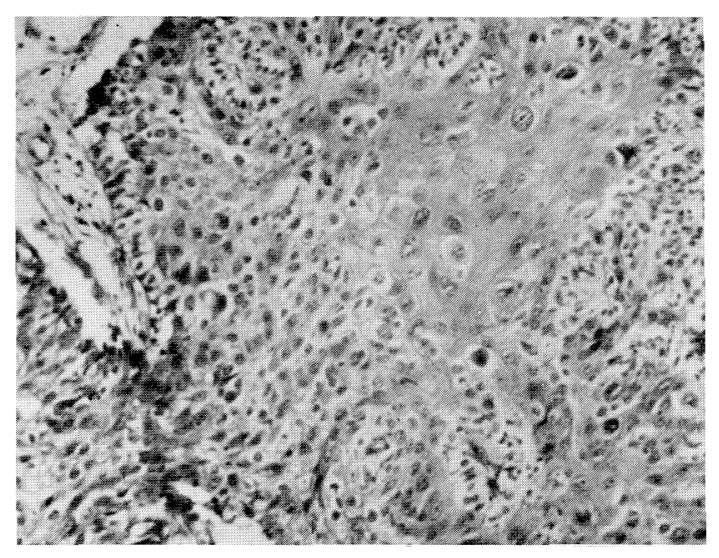

昭和 47 年 9 月，喀痰細胞㖣が陽性となり，再 入院，気管支鏡にて上葉支断端部に乳嘴状隆起 を認め, その対面側の主父管支粘膜も凹凸がみ られ，carinaにまで達していた。この時期の父 管断層像では，左右主父管支の狭管， carinaの 変形がみられた。(図4)

再発領域が広範囲に及ぶと考えられたため, lineac $6000 \mathrm{R}$ 照射し，血痰は停止した。その後
Fig. 3. Bronchography shows no abnormality.
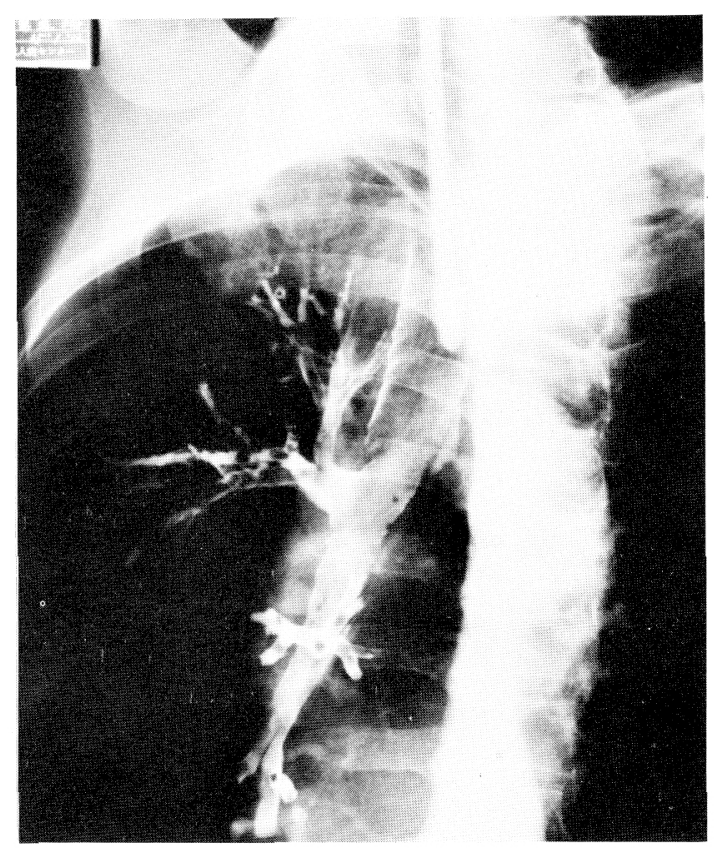

Fig. 4. Clinical course.

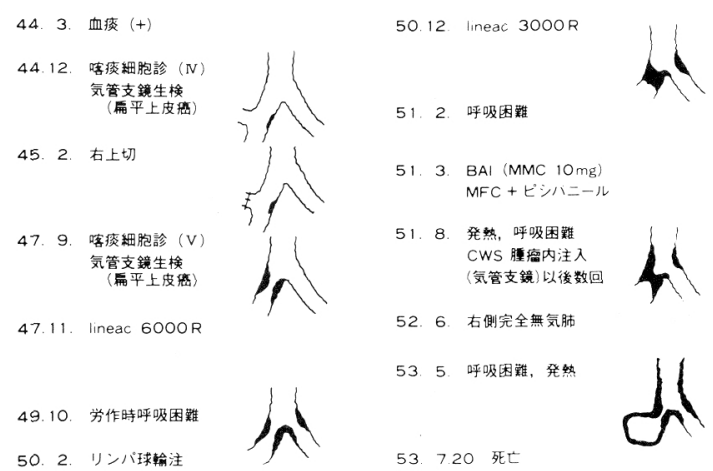

钼察を続けたが，とくに症状はなく、昭和49年

7 月の父管支鏡では上くに腫瘤状を呈する部は みられないが，擦過細胞診は陽性，気管支粘膜 面の不整，狭窄の進行がみられた。

49年11月頃から階段上昇時に呼吸困難感出現 し、時及発熱をみるようになった。また血痰が 1 日に2〜3 回出現するようになり，喀将量が 増加し, 痰の喀出が困難なときは呼吸困難を訴 えるようになった。50年12月には呼吸困難が持 続するようになり，匃管支鏡にて右主父管支の 
Fig. 5. Atelectasis and cavity formation in right lung.

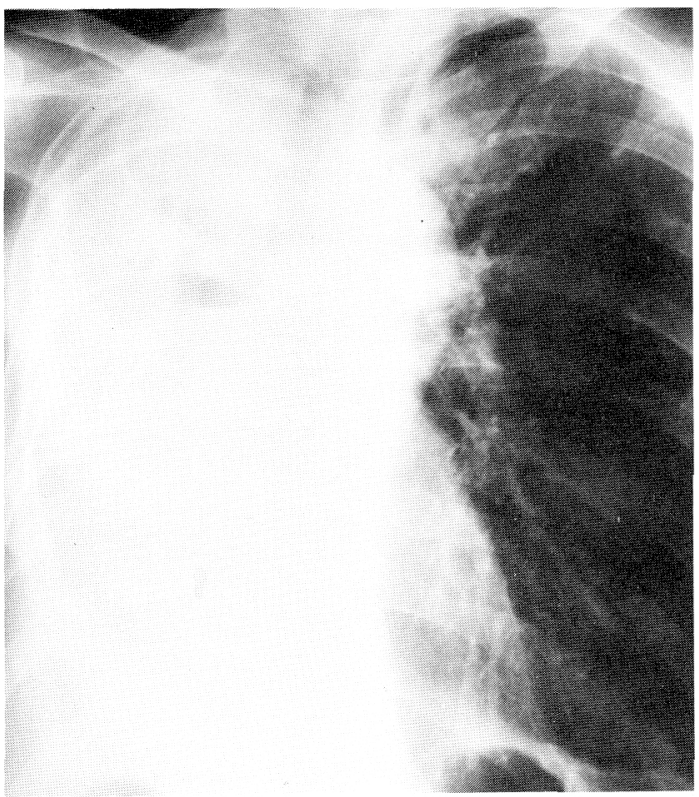

閉塞が認められたので, lineac 5000 R照射した。 照射により無父肺は改善したが，只の後分泌液 の喀出が相難なときは無気肺となり，発熱をき たすといった状態が反復するようになった。

51年 3 月, BAI (MMC 10mg) 施行したが, 効 果なく，続いてMFC6回施行したが効果は認め ら狄なかった。

51年8月上り，右主父管支閉塞部に匃管支鏡 により BCG-CWS $200 \mu \mathrm{g}$ 注入を施行し, 閉塞部の 壊死，無父肺改善を認め，52年 5 月まで計 6 回 反復施行した。この頃の父管支鏡所見では，父 管壁のかなり口側にも腫瘍性变化を認めた。

52年 6 月頃から，有肺は常時無気肺となり, その内部に透完像を認め，膿陽の形成が考之ら 孔た。(四 5 ) 発熱尧持続する上うになった。5 年になると，呼吸困難と発熱は持続し，53年 7 月20日, 死亡した。

全経過にわたって，表在リンパ節の腫張を触 知したことなく，また遠隔転移にもとづくと考 えら狄る臨休症状を認めたこともなかった。

剖検所是：右肺は完全に無父湖化，中央部は 膿瘍化している。左肺には急性気管支肺炎像か
Fig. 6. Lung in autopsy. Trachea and bronchi are opened from membranous portion. Tracheal and bronchial mucosa seem tumorous universally.

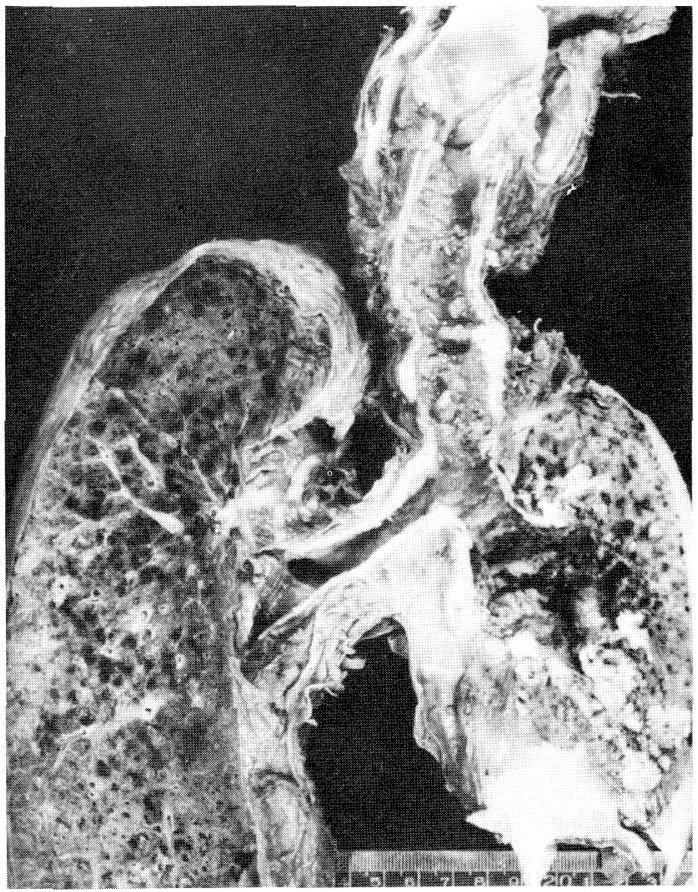

Fig. 7. Squamous cell carcinoma. No invasion into cartilage.

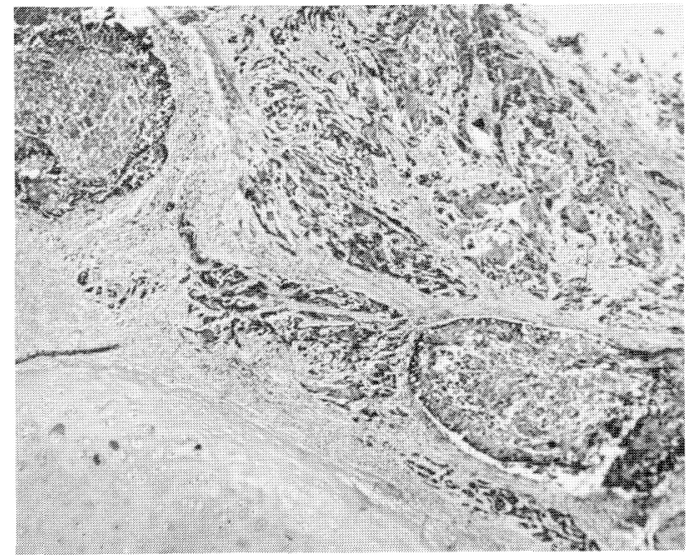

認められ，直接死因と考えられた。

気管・父管支を後面から膜様部で切開すると， 気管㧍よび左右主父管支内面の粘膜は全体に腫

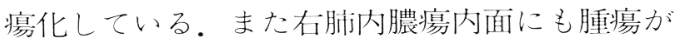
みら扎る。(四6)リン八節転移は少く, subca$\operatorname{rinal}($ No.7) とr.paratracheal(No.2)にそれぞれ 1 
Fig. 8. Tumor showes a wide bronchial wall development, mainly intramucosal.

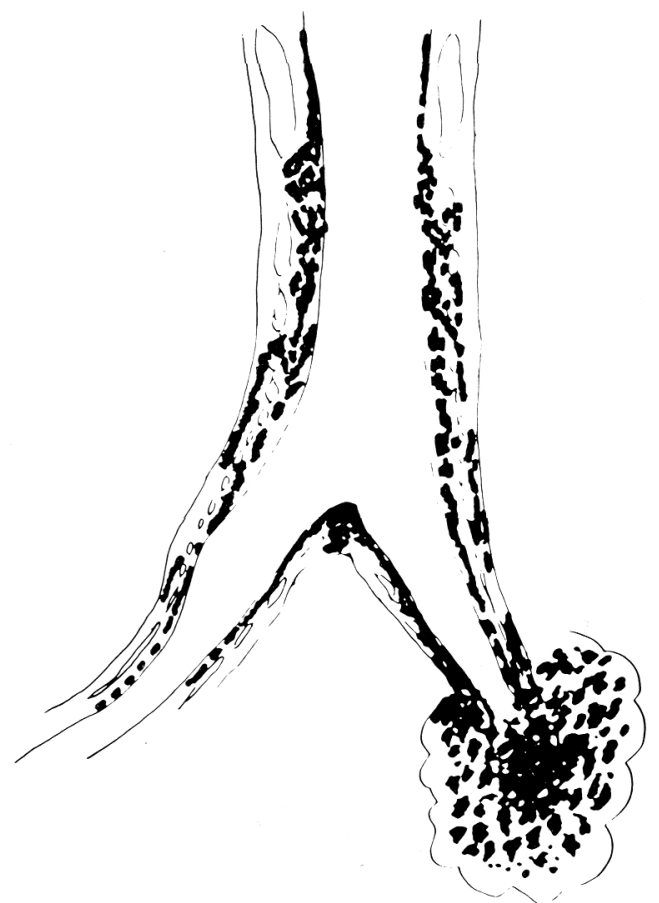

箇の転移リンパ節を認妨るみであった。腫瘍 の組織型は低分化扁平上皮癌であり，（闵７）, その進展形式を明らかに方るため，気管・父管 支を全長にわたって管状に摘出し，これを種久 の高さで，可及的多数の切片を作り，それぞれ の切片に扩ける腫演の存在部位から，本腫演の 経気管支性進展の状態をmapに古ると，（四8） 腫瘍は左側主気管支全面を侵し，父管では口側 では輪状軟悬部にまで達している。右肺内膿瘍 壁にも一面に認められた。また匃管・父管支壁 に㧈ける存在形式は，粘膜側を主とし，漿膜側 に腫陽が認められたのは, 右主気管支と, carina 直上部の気管のみであった。

\section{考察}

本症例は，初発時，主父管支発生の微少な非 隆起性屏平上皮癌であったが，手術時には，肺 門型早期肺癌の認識の浅かったことから，治癒 手術が行われなかった。しかし，死亡するまで

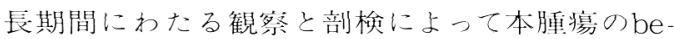
haviorを明らかにすることができた。
本腫䭲は，1)柕めて緩慢な経過をとったこと， $2)$ 粘膜側進展主とし, 順行性・逆行性に梌为 て広範囲に及んだこと，3)死亡時においても， リン八節転移・血行性転移は軽徽であったこと， という点で特異である。

腫㾇組織像からみると，発見時の父管支鏡生 枱時の標本(四 2)で，既に腫陽組織は基底膜を 越之，粘膜下組織に達しており，いわゆるcarci noma in situとはいえない。また剖検時におい ても(四 7 )，軟骨老破壊せず，粘膜側進展が主 である。大気管支発生の扁平上皮癌は多くは管 腔内に結節性に増殖し，父管支壁を鿓通子るリ ンパ管を通して墏膜側に到遧しこ、からリン パ行性に進展することが多い。著者らは、肺癌 40例について経父管支性の中枢側あるいは木梢 側に们う進展形式につむて検討したが, 検榃し た 126 検体中 67 検体 $(53.2 \%)$ に粘膜側進展孝, 91 㭘体 $(72.2 \%)$ に槳膜側進展をみとめた。これら のうち,粘膜側抽よび獎膜側ともに進展を認めた ものは50検体 $(39.7 \%) て ゙ あ り ，$ 粘膜側のみの進 展を示したものは17検体 $(13.5 \%)$, 牃膜側のみ

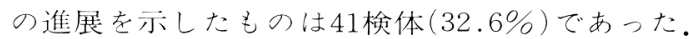

このような成績に照らしても，本症例の進展 形式は特異である。このよjな進展形式をとる 腫瘍のanalogyは胃のsuperficial spreading carci noma (Stout) ${ }^{3)}$ に求められよj。胃のsuperfici al spreading carcinomaは粘液産生の強い腺癌で あり，楖めて店い粘膜面進展を主とし，予後の良 好なこと，リンパ管侵龍の少いこと，リンパ節 転移の少いという特徵を有しており, 組織型の 差はあっても, その behavior は本症例とよく類似 している。

下里 $5^{5)}$ は肺門部早期屏平上皮嵒を肉眼所見 から，1)ポリープ型，2)結節浸㴸型，3)表層浸

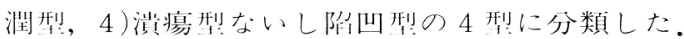
本例は表層浸潤型に相当すると思われるが，本 型の進展形式を示しているといえる。'

外科臨床的にみ扎ば，大父管支発牛の非隆起 性扁平上皮癌の中には，概めて広範囲の粘膜内 進展を呈するものがあるので，その切除に際し ては, 慎重な組織学的娭索が必要であることが 示されたといえよう。 
文 献

1）池田茂人編，肺門部早期肺癌困譜. p. 96 医学書院, 東京, 1976 .

2) 前田昌純, 岩本 熙, 門田康正, 中原数也, 木村謙太郎, 正岡 昭. 日胸外会誌, 18: 148,1970 .

3) Stout, A.P. Arch, Surg., 44, 651: 1942.

4）副島一彦, 井口 潔, 脇田政康, 児玉好史, 古沢元之助。胃と腸, $8: 1335,1973$.

5）下里幸雄, 雨宮隆太。池田茂人編, 肺門部早期 肺癌図譜. p. 29, 医学書院, 東京. 1976.

6) Woolner, L.B., David, E., Fontana, R.S., Andersen, H.A. \& Bernatz, P.E.

J. Thorac. Cardiovasc. Surg., 60:275, 1970.

（原稿受付1979年 2 月27日）

Clinical course and autopsy findings of a case with superficial infiltrating squamous cell carcinoma

\author{
Akira Masaoka*, Yasumasa Monden*, Yoji Seike*, Tsuneo Tanioka*, \\ Hajime Kitamura**, Hiroshi Izumi***, Yasoho Yamanashi***. \\ * The 1st Department of Surgery, \\ ** The 1st Department of Pathology, Osaka University Medical School. \\ ***Oosaka Chuo Hospital.
}

A 57 year-old male, who had a small squamous cell carcinoma at right main bronchus, was operated. However, a curative operation was not performed, because the tumor was not recognizable intraoperatively. He died after 8 years postoperatively. The autopsy revealed very wide intramucosal development, i.e. to cricoid cartilage and left main bronchus. Lymphnode and hematogenous metastases were minimal. This case may represent the clinical course of the superficial spreading type of squamous cell carcinoma from the stem bronchus, that is, slow growing, minimal metastasis and mucosal involvement in wide area. 